\title{
Investment in the Brazilian economy during the crisis
}

\section{ROBERTO MEURER*}

In this short article, it is analyzed as to whether financial flows and credit concessions explain the behavior of investment in the Brazilian economy during the 2008 crisis. Beyond the importance of demand, changes in expectations seem to be an important source of instability in investment and, as a consequence, in the economy.

Keywords: foreign portfolio investment; investment, expectations; 2008 crisis.

JEL Classification: E22; E27; F32.

Despite the initial thoughts that the financial crisis of 2008 could show a decoupling of emerging markets from the crisis hitting developed economies, it soon became evident that this would not happen. In this short article, the primary origins of the crisis will not be assessed, but it is worth noting the theoretical explanations based on regulation failure, the credit crunch after the housing bubble due to lax monetary policy, and transformations in the financial system (Bresser-Pereira, 2010; Brunnermeier, 2009; Crotty, 2009). These structural factors' transmission channels led to less output.

According to Keynes (1936), the dynamics of the economy is given by investment, as consumption is more stable. Expectations play a major role in the behavior of investment. Investment is difficult to forecast, and the instability of the economy derives from the uncertainty on expected returns. In this sense, there is a similarity between financial variables and investment, both reacting fast to changes in the economic environment and expectations, unlike consumption. It is important to highlight that Keynes portrays differences between entrepreneurs and professional investors, as behavior on expectations is different between the two groups.

\footnotetext{
* Professor do Departamento de Economia, Universidade Federal de Santa Catarina. E-mail: robertomeurer@yahoo.com. This paper was written while the author was a visiting scholar at UCLA Anderson School of Management, Los Angeles. Support from Capes is acknowledged. Submitted: 23/December/2010; Approved: 10/October/2011.
} 
Since it is difficult to measure expectations, financial flows can be seen as a proxy variable for the expectations, which include risk aversion changes. Foreign portfolio investment can account for expectations in the world economy, whereas credit concessions may reflect the state of expectations in the domestic financial system. It is not only expected returns but also the uncertainty about these returns that influences flows.

Given the strong fall in investment in the Brazilian economy during the 2008 crisis, this short article tests the relation between investment and real and financial variables, namely Gross Domestic Product (GDP), foreign portfolio investment, interest rate, and credit concession by the financial system. As shown in Figure 1, investment fell by $9.7 \%$ in the last quarter of 2008 and by another $12 \%$ in the first quarter of 2009. The investment level of the third quarter of 2008 was reached again only in the first quarter of 2010 . The GDP suffered a drop of $3.2 \%$ in the last quarter of 2008 and another $1.6 \%$ in the first quarter of 2009 .

Anecdotal evidence from the time of the crisis puts a strong weight for the fall in demand, and in output as a consequence, on a credit crunch, especially from the private banking system. Total credit concession in the financial system fell by $13.4 \%$ percent between the third quarter of 2008 and the first quarter of 2009. Recovery of credit concession began in the second quarter of 2009, and reached pre-crisis level by middle of 2010 (Figure 1). Since public and private credit does not react the same way to changes in expectations, using the aggregate value does not capture the whole impact of expectations. On the other hand, it allows taking into account the countercyclical behavior of the public banking system ${ }^{1}$. In the case of Foreign Portfolio Investment (FPI), the outflows and reversal to inflows are also observable. For interest rates, the crisis meant a strong fall in real rates from the beginning of 2009.

Figure 1: Variables of interest -200003 to 201002
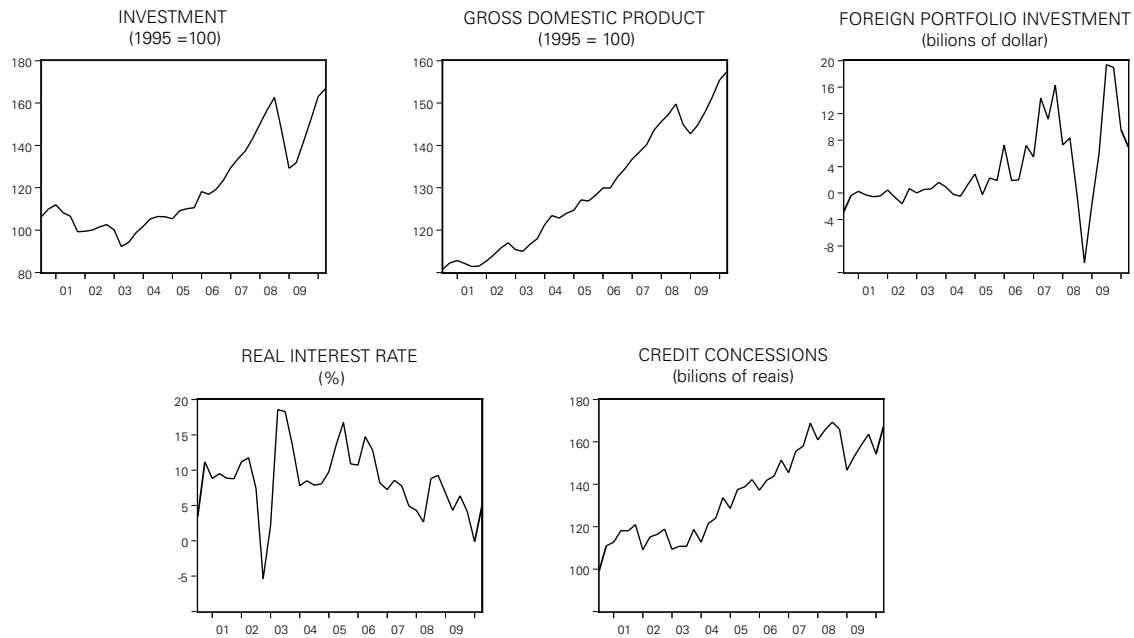

\footnotetext{
${ }^{1}$ The role of public banks during the crisis period is discussed in Araujo and Cintra (2011).
} 
The fall in investment and output at the end of 2008 and beginning of 2009 was too fast to be explained by the working of the restrictive monetary policy that was in course at the time. This means that expectations must have strongly changed, reacting to uncertainty in the world economy and also affecting Brazilian investors and the financial system. To test this hypothesis, Granger causality tests and regression analysis will be employed, using quarterly data from 2000Q3 to 2010Q2. The model to be estimated is theoretically and empirically in line with Oreiro, Nakabashi and Souza (2010), which emphasizes the role of demand for growth and investment.

The series for gross fixed capital formation (INV) and GDP are seasonally adjusted series obtained from Ipeadata, expressed in index number equaling the average of 1995 to 100 . The real interest rate $(\mathrm{R})$ is the real ex post quarterly average of the monthly SELIC interest rate using IPCA as the inflation rate, expressed in percentage per annum, calculated from data of the Brazilian Central Bank. Credit concessions in the financial system (CRCO) are the quarterly average of monthly concessions, expressed in billions of reais of June 2010, employing the IPCA as inflation rate, also obtained from the Brazilian Central Bank. Foreign portfolio investment traded in the country (FPI) is the quarterly flow expressed in billions of dollars, as published by the Brazilian Central Bank, transformed to constant values of the second quarter of 2010, using the U.S. consumer price index (CPI) as inflation rate. The FPI is the sum of net foreign portfolio investment in equity and fixed income traded in the country. The advantage of using flows due to securities traded in the country is that they include secondary market transactions, whereas the flows traded outside the country are mainly primary market operations. Since there is freedom to buy or withdraw securities in the country without relying on decisions of the issuer of the securities, the flows related to trade in the country are more capable of capturing changes in expectations by foreign decision makers. Foreign portfolio investment in equity and fixed income does not behave in exactly the same way, but it was chosen to work with the aggregate value instead of keeping them separated in order to get a single measure of market sentiment. This is also convenient, because the relative participation of each flow changed over time. Fixed income flows are more important since 2006, due to a change in income tax on foreign investors. The INV and GDP series are seasonally adjusted by IBGE, which calculates Brazilian national accounts. From the other series, CRCO was the only one to show the presence of seasonality, which was removed through the Census Arima X12 software. INV, GDP, FPI, and CRCO are employed in natural logarithms, indicated by the $\mathrm{L}$ in the name of the variables LINV, LGDP, LFPI, and LCRCO. In order to get positive values in all periods and use logarithms, the arbitrary value of 15 was added to the original FPI series.

$\mathrm{ADF}$ and PP tests (not shown but available on request) found that LINV, LGDP, and LCRCO are stationary in first differences, whereas LFPI and R are stationary. Since LINV, LGDP, and LCRCO are I(1), they could be co-integrated. The Johansen test indicated the presence of two co-integrating vectors, but these were not statistically significant in the short run equation for changes in invest- 
ment (results not shown but available on request). These results mean that it is necessary to work with the first differences of LINV, LGDP, and LCRCO, respectively, DLINV, DLGDP, and DLCRCO, in order to avoid spurious results in the regressions.

Table 1 shows the results of Granger causality tests. Results significant at the $10 \%$ level are highlighted in bold. The rejection of the null hypothesis of no causality means that the explanatory variable helps explain the behavior of the explained variable. Causality, in this sense, means precedence in time. The tests were carried out for the subsample 2000Q3-2008Q3 and the whole sample 2000Q3-2010Q2 in order to detect changes in the relationships between the variables due to the crisis. The maximum lag tested was for six quarters, coherent with the maximum lagged effect of the monetary policy on output and inflation according to the Brazilian Central Bank (Banco Central do Brasil, 2009). The optimal lag was chosen as the longest of Schwarz, Akaike, and HQ optimal lag criteria and the Wald test for lag exclusion.

The importance of demand, detected in Oreiro, Nakabashi and Souza (2010) is confirmed by DLGDP preceding DLINV, but not the other way around. There is evidence of the role of expectations, as LFPI anticipates the behavior of DLINV in the pre-crisis subsample and the whole sample. This role seems to be even stronger when the crisis period is included in the sample, when DLINV also anticipates LFPI. This means that when investment fell at the beginning of the crisis, then the financial outflows began even before the crisis, but after the crisis investment reinforced the FPI inflows. A main role for expectations can be seen as the link between interest rates and investment vanishes when the whole sample is considered. Up to the crisis, there is no causality between DLINV and DLCRCO, but for the whole sample, DLINV anticipates DLCRCO. This result could mean that investment not only reacts even faster than credit concessions when the crisis period is considered, but it also is influenced by the reaction of credit concessions since the beginning of 2009 , mainly via the public banks system, which allowed for a faster recovery of investments. The relevance of the financial system is highlighted by the relation between DLGDP and DLCRCO, significant when the crisis period is included in the sample, but not before. Influence of expectations also appears in the fact that LFPI anticipates the behavior of DLGDP before and after the crisis. The expectations that influence foreign investors as well as the local financial system seem to turn more coordinated with the crisis, thus turning significant the anticipation of DLCRCO by LFPI ${ }^{2}$.

\footnotetext{
${ }^{2}$ The Granger causality tests were also carried out with the FPI flows disaggregated in equity and fixed income. For equity flows, results were the same except for one for the whole sample, but none of them was statistically significant for the pre-crisis period. For fixed income flows, there are fewer significant relations, probably because these flows have more relevant volumes only since 2006 .
} 
Table 1: Granger Causality Tests-Probabilities of the F-test of rejecting the null hypothesis

\begin{tabular}{|c|c|c|c|}
\hline - Null Hypothesis: & Lags & $\begin{array}{l}200003- \\
-200803\end{array}$ & 2000Q3-2010Q2 \\
\hline DLGDP does not Granger Cause DLINV & 1 & 0.0003 & 0.0004 \\
\hline DLINV does not Granger Cause DLGDP & 1 & 0.5774 & 0.4766 \\
\hline LFPI does not Granger Cause DLINV & 1 & 0.0830 & 0.0001 \\
\hline DLINV does not Granger Cause LFPI & 1 & 0.9553 & 0.0993 \\
\hline R does not Granger Cause DLINV & 2 & 0.0596 & 0.2963 \\
\hline DLINV does not Granger Cause R & 2 & 0.3995 & 0.6544 \\
\hline DLCRCO does not Granger Cause DLINV & 2 & 0.5945 & 0.7075 \\
\hline DLINV does not Granger Cause DLCRCO & 2 & 0.3105 & 0.0925 \\
\hline LFPI does not Granger Cause DLGDP & 4 & 0.0606 & 0.0436 \\
\hline DLGDP does not Granger Cause LFPI & 4 & 0.2041 & 0.6480 \\
\hline R does not Granger Cause DLGDP & 4 & 0.3723 & 0.9281 \\
\hline DLGDP does not Granger Cause R & 4 & 0.2316 & 0.4046 \\
\hline DLCRCO does not Granger Cause DLGDP & 3 & 0.1505 & 0.0629 \\
\hline DLGDP does not Granger Cause DLCRCO & 3 & 0.1382 & 0.0355 \\
\hline R does not Granger Cause LFPI & 2 & 0.6815 & 0.4973 \\
\hline LFPI does not Granger Cause R & 2 & 0.6709 & 0.6614 \\
\hline DLCRCO does not Granger Cause LFPI & 6 & 0.6273 & 0.6036 \\
\hline LFPI does not Granger Cause DLCRCO & 6 & 0.8023 & 0.0329 \\
\hline DLCRCO does not Granger Cause R & 3 & 0.1429 & 0.1476 \\
\hline R does not Granger Cause DLCRCO & 3 & 0.2819 & 0.2080 \\
\hline
\end{tabular}

Note: Optimal lag chosen according to the longest lag between Schwartz, Akaike, and Hannan-Quinn criteria and Wald lag exclusion test.

As a robustness check, regressions using the general-to-specific approach beginning with four lags and leaving only the significant variables in the model were also estimated (Table 2). The models are estimated for the subsample 2000Q3 to 2008Q3 and for the whole period. Since investment is a part of GDP and both are highly correlated, the contemporaneous GDP and lagged investment were excluded as explanatory variables. In general, results are consistent with the Granger causality results and confirm the demand-led hypothesis. Lagged DLGDP has a high positive influence on DLINV. Portfolio investment has a positive relation with DLINV in both estimations, but the influence seems to be faster when the crisis period is included in the estimation sample, with contemporaneous and shorter lags being statistically significant. There is a positive relation between interest rate and investment in the second lag, which is consistent with a forward-looking and countercyclical monetary policy. The negative effect of R on DLINV in the third lag is in line with the lagged effects of monetary policy on real variables. Credit conces- 
sions have a strong positive relation with investment in both specifications. In this case, it can be seen that expectations which influence the financial institutions also influence investment. This channel does not show relevant changes between the two samples. This helps explain the fall in investment when financial institutions withdraw from credit concessions. On the other hand, the effort of the Brazilian government to keep the credit market working by stimulating credit from official banks was correct, and it eased the investment downturn according to these results.

Table 2: Regression results - Dependent variable: DLINV

\begin{tabular}{|c|c|c|}
\hline & $\begin{array}{c}\text { 200104-200803 } \\
\text { Coefficient } \\
\text { (t-stat) }\end{array}$ & $\begin{array}{c}\text { 200104-2010Q2 } \\
\text { Coefficient } \\
\text { (t-stat) }\end{array}$ \\
\hline CONSTANT & $\begin{array}{r}-0.1811 \\
(-3.56)\end{array}$ & $\begin{array}{r}-0.2103 \\
(-3,68)\end{array}$ \\
\hline DLGDP(-1) & $\begin{array}{c}0.9988 \\
(1.95)\end{array}$ & $\begin{array}{l}1.3736 \\
(3.04)\end{array}$ \\
\hline DLGDP(-4) & & $\begin{array}{r}-0.8716 \\
(-2.38)\end{array}$ \\
\hline LFPI & & $\begin{array}{c}0.0378 \\
(3.27)\end{array}$ \\
\hline LFPI(-1) & & $\begin{array}{c}0.0599 \\
(4.05)\end{array}$ \\
\hline LFPI(-2) & & $\begin{array}{c}-0.0572 \\
(-3.92)\end{array}$ \\
\hline LFPI(-3) & $\begin{array}{l}0.0613 \\
(3.50)\end{array}$ & \\
\hline LFPI(-4) & & $\begin{array}{c}0.0356 \\
(2.76)\end{array}$ \\
\hline $\mathrm{R}(-2)$ & $\begin{array}{c}0.0022 \\
(2.72)\end{array}$ & $\begin{array}{l}0.0019 \\
(2.21)\end{array}$ \\
\hline $\mathrm{R}(-3)$ & $\begin{array}{r}-0.0013 \\
(-1.71)\end{array}$ & $\begin{array}{r}-0.0026 \\
(-3.30)\end{array}$ \\
\hline DLCRCO & $\begin{array}{c}0.6382 \\
(3,67)\end{array}$ & $\begin{array}{l}0.5102 \\
(3.00)\end{array}$ \\
\hline DLCRCO(-2) & & $\begin{array}{c}0.3525 \\
(2.16)\end{array}$ \\
\hline DLCRCO(-3) & $\begin{array}{c}-0.6052 \\
(-4.07)\end{array}$ & $\begin{array}{r}-0.5024 \\
(-3.59)\end{array}$ \\
\hline DLCRCO(-4) & $\begin{array}{c}0.3136 \\
(2.09)\end{array}$ & $\begin{array}{c}0.2737 \\
(1.99)\end{array}$ \\
\hline $\mathrm{R}^{2}$ & 0.83 & 0.92 \\
\hline
\end{tabular}


Regression results show the important role played by expectations with regard to investment, which remained in place during the crisis, and helps explain the downturn and recovery of the Brazilian economy. Observed and estimated values for investment based on the regression results of Table 2, along with out-of-sample forecasts based on the 2001Q4-2008Q3 results, are shown in Figure 2. The out-ofsample forecasts were calculated with the observed explanatory variables. The forecasted values were transformed back to the original index. As expected, the disruption in the economy caused by the crisis led to poor out-of-sample forecasts, but the in-sample fit was very good. The MAPE (mean absolute percentage error) for the out-of-sample forecast is $7.1 \%$, whereas for the same period, it is only $0.7 \%$ based on the whole sample estimation. This means that the poor forecasts are due to big changes in the value of the explanatory variables, which are taken into account for the whole sample estimation. The high level of uncertainty about the future of the Brazilian economy, reflected in portfolio investment and credit concessions, is in line with the expectations that also affect entrepreneurial investment and helps explain the good fit of the estimated model even when the crisis and recovery period is included in the estimation sample.

Figure 2: Observed and estimated values of Investment

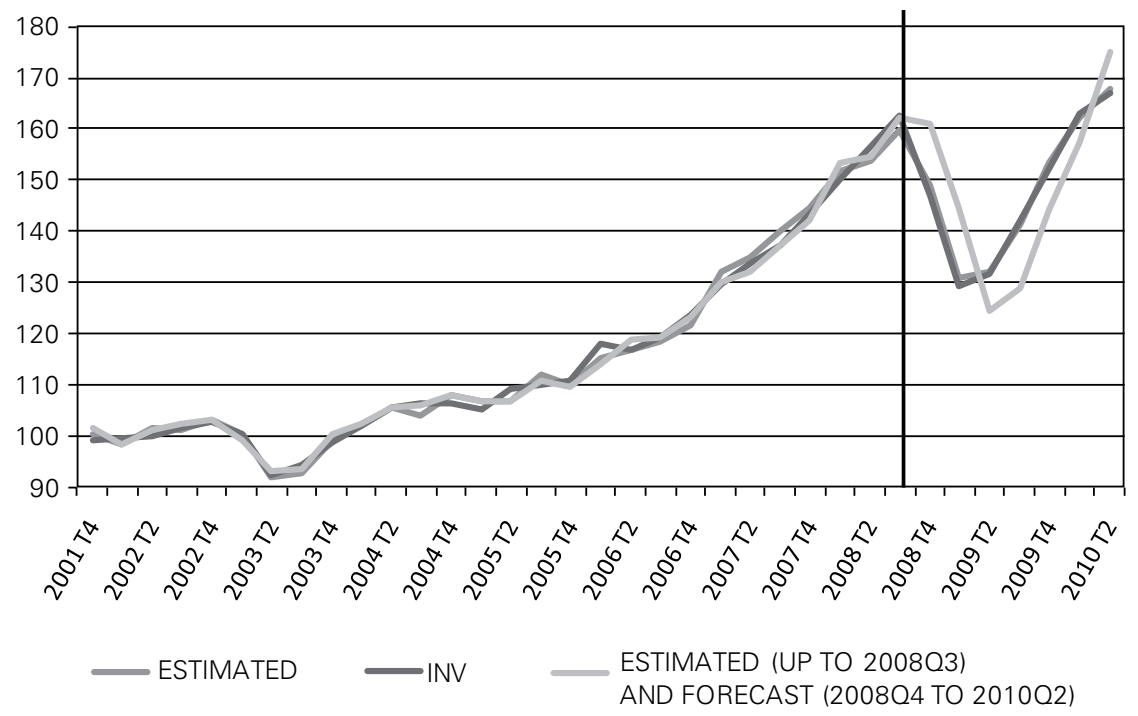

Since it is impossible to forecast uncertainty, its real effects are even more pronounced in times of crises. Wide swings in expectations lead the Brazilian economy to instability. According to the results of the Granger causality tests and the regressions, the reduction of interest rates and the use of public financial institutions to act contrary to the reduction in credit concessions helped the recovery of investment. The lower external vulnerability in comparison to other crises episodes made expectations about the Brazilian economy turn positive in the beginning of 
2009, similar to the expectations that explain investment. Monetary and credit policies were important to the recovery of the Brazilian economy.

\section{REFERENCES}

ARAUJO, Victor Leonardo; CINTRA, Marcos Antonio Macedo (2011). "O papel dos bancos públicos federais na economia brasileira”. IPEA, Texto para discussão 1604.

BANCO CENTRAL DO BRASIL (2009). "A defasagem da transmissão da política monetária para preços”. In: Relatório de Inflação, 11(2): 125-128.

BRESSER-PEREIRA, Luiz Carlos (2010). "The 2008 financial crisis and neoclassical economics. Revista de Economia Politica, 30(1): 3-26.

BRUNNERMEIER, Markus K. (2009).” Deciphering the liquidity and credit crunch 2007-2008”. Journal of Economic Perspectives, 23(1): 77-100.

CROTTY, James. (2009). "Structural causes of the global financial crisis: a critical assessment of the 'new financial architecture"”. Cambridge Journal of Economics, 33(4): 563-580.

KEYNES, John Maynard (1936 [1991]). The General Theory of Employment, Interest and Money. New York, Harcourt Brace.

OREIRO, José Luis; NAKABASHI, Luciano; SOUZA, Gustavo J.G. (2010). “A economia brasileira puxada pela demanda agregada”. Revista de Economia Politica, 30(4): 581-603. 